\title{
Education for Responsible Citizenship: A Challenge for Faculty Developers
}

\section{Thomas Ehrlich}

San Francisco State University

The Carnegie Foundation for the Advancement of Teaching

Higher education professionals need clearer, stronger frameworks for the integration of both civic and moral learning and the more common cognitive learning that occurs in traditional classrooms. This article addresses when and why this author chose to focus on community service-learning as a way to reengage in direct work with students and other civic responsibilities. His discussion focuses on student acquisition of academic knoweledge and skills through service-learning and the study of ethical dilemmas facing professionals in different fields. He proffers indepth discussion on service-learning programs championed by the Carnegie Foundation and addresses how these programs working with faculty across the country ground their philosophy in moral and civic responsibility. Finally, and in some ways most importantly, he discusses bow all of us in higher education need clearer, stronger frameworks for the integration of both civic and moral learning and the more common cognitive learning that occurs in traditional classrooms.

\section{INTRODUCTION}

Twas eight years old in 1942 when my family moved to Washington, IDC, where my father served in the Office of Price Administration. My major civic involvement during World War II was contributing my mother's iron to a scrap drive being held by a local movie house, which promised free admission in exchange for a ten-pound contribution. My mother was not thrilled at losing her only means of pressing clothes, but I felt very patriotic. 
Twenty years later, I moved back to Washington with my family to serve in the Kennedy administration. I took seriously the charge to "ask what you can do for your country," and my experience confirmed what my father had taught me-the opportunity to engage in public service is one of life's true privileges. It gives purpose to one's life as well as pleasure. Public service can take many different forms, but it is a common calling in every sense.

During my first tour in Washington, I worked for George W. Ball as he sought to persuade President Johnson that the war in Vietnam was a mistake. That effort failed, but I left government service to teach with a profound sense that every citizen has an obligation to strive for a better America, and that whether my vocation was civil servant or teacher, my avocation had to be some form of civic involvement.

As a law school professor and then dean at Stanford University, I became increasingly troubled that the public profession of law-and law schools such as mine-ignored poor people, those most in need of using the legal system, those most abused by the system. And I found that lawyers were generally unwilling-really, I think, they were emotionally unable - to provide their time and talent pro bono to do public work with poor people. Over and over I heard attorneys say that "They just wouldn't be comfortable with me," meaning that the speaker wouldn't be comfortable with them. Public service, I came to learn, is an acquired taste, and while one is never too old to begin, it certainly helps to start at an early age.

When I left Stanford to head the Legal Services Corporation, which funds civil legal help for the poor, I learned again and again what a privilege it is to do public work. And when I had the good fortune to try to run the foreign aid program for President Carter- "run" is hardly the right verb-I had more lessons in that same course of study.

I departed from my foreign aid position on the day President Reagan was inaugurated, and, as when I left Washington during the Vietnam War, I was disappointed by much that was government policy. But I never lost my commitment to public work, or public service as I still call it. In various ways since then, I have been engaged in encouraging young people to make that commitment and to act on it. The University of Pennsylvania, where I was provost, and Indiana University, where I served as president, both offered super opportunities to put commitment into practice. I have been particularly pleased by the remarkable growth of the national organization, Campus Compact, in which I have been much involved. It began with a small group of presidents in 1985, and includes about 650 presidents today. 
I am deeply troubled, however, by clear evidence of what Wendy Rahn (1998) of the University of Minnesota terms "the steep erosion in support for the American political community among younger generations. Americans socialized in more recent decades have less positive and more negative feelings when thinking about the country than older generations, attach less personal importance to their American identity, [and] are less likely to value citizenship as an important attribute of American identity ... " (p. 3).

\section{Pedagogies of Engagement for Civic Responsibility}

When I decided to leave university administration and return to teaching at San Francisco State University and writing at the Carnegie Foundation for the Advancement of Teaching, I focused on community servicelearning as a way to reengage in direct work with students and their civic responsibilities. Over the previous decade, I taught a number of undergraduate courses that linked community service and academic study through structured reflection-at Indiana University and Duke University. In each of those community service-learning courses, I sought four interrelated clusters of learning goals: academic learning, social learning, moral learning, and civic learning.

Academic learning was the starting point for most of those courses. Community service is an integral part of my course on "Ethics and Professions," for example, primarily because I am convinced that the students gain more academic knowledge and skills than they would without that service, as we consider ethical dilemmas facing professionals in different fields. This is no less true of a course, "Law and Society," in which we examine the impact of law and lawyers in shaping American society from Puritan days to the time of O. J. Simpson and the impact of American society in shaping the legal system. The primary reason students in that course engage in community service, usually related to juvenile justice, is that they gain a deeper understanding of the interactions of law and society, in both personal and policy terms.

At the same time, I believe that students in these courses gain social, moral, and civic learning as well. By social learning I mean interpersonal skills such as careful listening, sympathy for others, and the ability to lead, to compromise, to change one's mind, and so forth, as well as personal traits such as self-esteem-skills that are important to personal interactions in any social setting and vital to success in most careers.

Moral learning, on the other hand, refers to helping students think 
about themselves in relation to others-who are their neighbors and what are their obligations to their neighbors? Service connects thought and feeling in a deliberate way, creating a context in which students can explore how they feel about what they are thinking and what they think about how they feel. The interaction of academic study and community service, guided by reflection, offers students opportunities to consider what is important to them-and why-in ways they too rarely experience otherwise. This dimension of learning was primary in a seminar that I offered on "Altruism, Philanthropy, and Public Service." It was designed particularly to enhance students' moral character by challenging their personal reactions to moral situations in both their readings and their community service, and by reflecting on those reactions in class discussions, papers, and personal journals.

In each class I tried to evaluate the results through surveys of attitudes and by considering the portfolios of students' work taken as a whole. Measured by what students reported, and by some rudimentary reviews of student attitudes, the results were encouraging in terms of academic, social, and moral learning, though in different degrees for different courses. When I tried to assess impact of these courses on civic learning, however, they seemed to fall short. By civic learning I mean coming to understand how a community functions, what problems it faces, the richness of its diversity, the need for individual commitments of time and energy to enhance community life, and most of all, the importance of working as a community to resolve community concerns.

Benjamin Barber (1992) of Rutgers, Robert Putnam (1995) at Harvard, and many others have stressed that community service is one of the most important ways, often the most important, to counter a seeming trend of civic disengagement among students. Civic learning-in the sense of how a community works and how to help it work better-and academic learning should be mutually reinforcing, as John Dewey (1916, 1938) emphasized. But I found it hard to confirm to myself, let alone to others, that my courses were having much impact on the civic learning of my students, in ways that I could regard as academic, social, and moral learning, though I stress that all four dimensions are closely related and reinforcing.

I found myself increasingly speaking out about the importance of community service-learning as an antidote for the decline of social capital and the fractionation of community that Putnam has chronicled. But how did I know, I kept asking myself? How sure was I that as a result of my courses, the civic learning quotient of my students was really 
enhanced? And, in all events, couldn't I do better if I were to focus squarely on civic learning, against the background of what I had learned through other courses and by reading of the work of other faculty? That is exactly what I did over the past year.

I began by reflecting on my own courses and by reading about others that seek explicitly to "experience citizenship," in the fine phrase that is the title of the AAHE service-learning monograph on political science. Taken as a whole, that volume; other publications, particularly from Campus Compact; and my own experiences suggested that service-learning should be linked to two other powerful pedagogies: problem-based learning and collaborative learning. Taken together, these three pedagogies reflect the three key elements that John Dewey stressed in the democratic learning process:

1) Process should engage students in reaching outside the walls of the school and into the surrounding community, as is the aim of community service-learning, as opposed to closed classroom learning.

2) It should focus on problems to be solved, as is the basis of problembased learning, as opposed to discipline-based learning.

3) It should be collaborative, both among students and between students and faculty, as is the aim of collaborative learning, as opposed to individual learning.

Problem-based learning has been emphasized by some higher education faculty for a long time, but has received increased attention in recent years. The essential element is not simply that problem-based courses are interdisciplinary or multidisciplinary, but rather that a problem is the starting point in designing a course. As students advance, they tackle increasingly difficult problems using increasingly sophisticated techniques and increasingly complex knowledge bases. The problem approach, as Dewey taught us, is a key in preparing students for active participation in the ongoing renewal of democracy. That renewal involves much more than attention to the minimum responsibilities of a citizen - to vote and to participate in various civic organizations-though these responsibilities are certainly both important and ignored by most citizens today. But democracy also calls for citizens to identify community problems and to work communally to resolve those problems. At its best, the problembased learning can further this key objective of civic learning.

Collaborative learning also has a long history and is increasingly part 
of undergraduate education. As president of Indiana University, the most common criticism I heard from employers was that our graduates were ill-trained to work as members of a team. Although most of the tasks these graduates would be called upon to perform in the workplace would be done as team members, most of their undergraduate work was done alone. Collaborative learning is a pedagogy particularly targeted toward enhancing the skills and abilities required to be a productive team member. It is also integral to a democratic society in which citizens interact with each other, learn from each other, grow with each other, and together make their communities more than the sum of their parts. Dewey urged that a community of learners is the primary mechanism through which this democratizing process can best occur. Collaborative learning, at its best, offers an opportunity to put this exhortation into practice.

Dewey's vision and his cautions about a democratic society underscore the importance of both these pedagogies. The vision was of an interactive, collaborative society in which the processes of decision on how to solve a problem are more important than the problem itself. It was balanced by cautions that uncertainty surrounds every decision about a problem, and every fact on which a decision is based. Those pedagogies are important for their potential to strengthen civic learning, and they are particularly powerful when combined with community service-learning. Community service-learning is their natural pedagogical partner. Community service-learning enables students to put into practice what they gain in academic study and to bring insights from service directly to their consideration of academic analysis. In my grazing through the fields of higher education in recent years, seeking tutorials about community service-learning courses, this troika repeatedly appears as a powerful combination.

\section{Practicing What I Preach}

On this basis, I sought to shape a new course at San Francisco State University that would employ all three pedagogies. The next step was to sit down with a group of civic leaders in San Francisco to discuss the elements they thought were important in civic leadership and the design of a project to enhance those elements in our students. Fortunately, the Urban Institute of San Francisco State University was a ready ally in reaching this group. The institute serves to link the university and its strengths with the city, its opportunities, and its needs. The institute 
sponsors a series of projects that promote student and faculty learning and research on the one hand and the resolution or amelioration of city concerns on the other. The institute is both an academic and an administrative unit, reporting directly to the university president, Robert Corrigan, himself a champion of preparing students for lives of engaged citizenship. The institute is also the home of the office of community service-learning, which supports faculty and students in a wide range of community service-learning courses.

The Urban Institute recently joined with a nonprofit civic group to form the San Francisco Policy Center. The center is a gathering of civic leaders from various sectors of the City-including community-based organizations, business, labor, and education - who came together to design programs that could use the resources of the university to assist the city. A number of those programs are underway, particularly in the arena of job training. Over the course of numerous sessions I sought the counsel of this group in shaping the pilot project. The leaders had different perspectives on almost every issue we considered, but they were united in their concern that a new generation of civic leaders was not apparent in San Francisco, and in a desire to share in the education of their successors. We discussed at some length what cluster of issues would work best as a focus for the project. Like most urban centers, San Francisco faces no end of tough problems. Among those we considered were municipal transportation; employment strategies; juvenile crime; a controversy about a major freeway running through the city; health issues, particularly AIDS; environmental concerns; and San Francisco neighborhoods in the wake of federal and state welfare reform. In the end we chose the last of those topics. I am now convinced, however, that any of them could have worked well for the civic education goals we established, because all of them related to disadvantaged groups in the city and broad issues of social justice. This meant we excluded such controversial questions in the city as the chaos caused by cyclists who demanded more attention on the bridges coming into the city and on the city streets. This is a tough cluster of issues, but not one that affects many poor or low-income people.

From the outset, based on advice from the members of the policy center, we planned that a centerpiece of the project would be a forum of civic leaders from a range of perspectives who would discuss the topic chosen and to try to reach common ground. This meant that the topic would have to have real importance, and ideally, so would the forum in terms of other places in which civic leaders argue their case in San Fran- 
cisco. There had to be a clear sense that the issue was worth discussing on its own merits-the pedagogical program must be attached to something real. If, for example, all significant concerns regarding municipal transportation were going to be decided through collective bargaining, then a forum on that topic would not be appropriate. In the worse sense, it would have been an academic exercise.

We also concluded that care was needed in defining the issue so that it was broad enough to be of center stage importance and specific enough to be resolvable. Crime was too big. What caliber guns should be carried by police was too small. Juvenile crime, or the proper role of citizen review boards, and the question of civilian control over the police, might be just right. We also concluded that to be successful, the project needed to enable students to:

- read and discuss relevant materials

- interact with civic leaders who are working on a real city problem

- work themselves on that problem

- reflect on what they have learned in the realms of theory and practice and how/whether the two connect

In the end, we concluded that the impact of welfare reform on San Francisco neighborhoods would be ideal, primarily because the civic leaders thought it a central concern on which discussion among two different groups of civic leaders was needed. One group was those familiar with issues of public housing; the other group was those familiar with welfare and welfare reform. Neither group had spent much time talking to the other. The forum would provide a useful opportunity to do that, and the work of the students could be of direct benefit to both groups. At the same time, I stress my conviction that we could have chosen, for example, employment strategies, and engaged in an equally productive project from the perspective of civic education. In the years ahead, I hope to test that belief.

The choice of San Francisco neighborhoods in the wake of welfare reform was also made easier because my co-teacher, Lori Bamberger, has a wealth of knowledge about urban housing issues. Although the primary course goals were centered on civic learning, not learning about housing or welfare, the one could not occur without the other, and Ms. Bamberger brought particular strengths in the housing field. From the outset, we designed and taught the course together, she bringing strengths 
relating to urban development and I ones having experience relating to civic responsibility.

We chose two complementary sets of materials for the course-one on civic responsibility - primarily readings from Barber and Battistoni (1993), "Education and Democracy,"-and one on issues of urban poverty-primarily readings from Danzinger, Sandefur, and Weinberg (1994), "Confronting Poverty: Prescriptions for Change." Each class was designed to move back and forth among questions raised in these materials so that the issues of civic responsibility were handled in terms of their impact on concerns about urban poverty, and problems of urban poverty were viewed as matters of civic concern.

In one class session, for example, the focus was immigration, citizenship, and welfare reform. We considered the implications of welfare reform for immigrant households, children, the elderly, and the disabled. We asked whether place of birth was a fair way to discriminate in the allocation of government benefits; whether place of birth should be the primary criterion for citizenship; whether citizenship should be a primary criterion in the distribution of welfare. What should be the citizenship test for immigrants? We also focused specifically on the implications of the welfare reform legislation in targeting elderly and disabled immigrants for benefit reductions; e.g., the effect of restricting eligibility for food stamps, and so forth.

We built the course around the forum, which met during the third week of classes. In preparation for that session, students read a sufficient amount of material to have a basic understanding of both current housing and welfare rules in San Francisco, and particularly how the new federal and state legislation was creating massive shifts in eligibility for public benefits among poor people. The forum brought together 22 civic leaders from city government, nonprofit organizations, the Chamber of Commerce, and private business concerns. It was the first time that the group as a whole had come together, though many of them knew and had worked with each other. Students were mainly observers, but they had an opportunity to ask questions and to mingle with the civic leaders before and after the forum. During the three-hour forum, Ms. Bamberger led a structured discussion and debate on the options available to the city and the organizations present, and how best to take advantage of the least painful paths in support of poor people. Students said they came away inspired by the leaders, sobered by the challenges that had been raised, and committed to work on those challenges.

All the members of the forum agreed to assist the students in their 
work. Apart from readings and class discussions focused on those readings, the students had two other closely related clusters of responsibilities. The first was to spend at least five hours per week in a community service agency that helps welfare recipients. Ms. Bamberger and I had identified seven community agencies that met this criterion and had offered to assist in the course. The leaders of those agencies were also participants in the forum. Arriba Juntos, for example, is a Latino, community-based organization that helps families achieve self-sufficiency, with a particular emphasis on job-training. Chinatown Community Development Center, on the other hand, is a neighborhood-based housing and community development organization that provides services to low-income tenants.

The only agency not directly related to welfare or housing was a group called Students Helping in the Naturalization of Elders (SHINE). This is a program to train and enable students to be citizen coaches for immigrants who are studying for the naturalization examination. The students working at SHINE helped immigrants gain citizenship knowledge and skills and in the process strengthened those skills themselves. The course easily could have been developed around a substantive focus on poor immigrants and their problems in San Francisco, with all the students serving in SHINE, and also working on substantive issues similar to those we considered, but with a particular concentration on immigrants.

We made significant efforts throughout the course to link the students' community service to the readings on both civic responsibility and poverty through class discussions and a brief paper that each student wrote as a publicity brochure for her or his agency. A number of these papers were good enough to be used by the agencies involved. The other main link between academic study and community service was an extensive field project that students worked on in teams of four or five in the four San Francisco neighborhoods that include most welfare recipients: Mission, Bayview/Hunters Point, Visitacion Valley, and Chinatown. In most cases, the students in each team were also working in a community service agency in the neighborhood where they were also doing their field study. We gave them a substantial set of background materials full of data about demographics, housing, and poverty, as well as studies that had previously been done on San Francisco public housing and welfare issues. None of the prior studies had examined the impact of welfare reform on these four neighborhoods, and the students did not need to do any library research. Rather, each team prepared a "Neighborhood Study on the Impact of Welfare Reform" consisting of demographic data particular to the neighborhood, including the prevalence of welfare recipiency, average 
income levels, and so forth; an objective summary of the welfare-related needs of the neighborhood arising out of welfare reform-how many households will need jobs, child-care, transportation, and other projected impacts; housing stock information; summaries of residents' concerns, and the concerns of businesses, about welfare reform; summaries of welfare-related services, such as job-training and child-care, available to neighborhood residents; options and recommendations for giving priority in housing assistance; commentary on how the recommendations of a housing task force established by the San Francisco mayor would affect the neighborhood; neighborhood analysis of one of the numerous citywide proposals for helping poor people; and finally an action plan for the neighborhood.

This is an ambitious agenda, but the students were assisted by a detailed protocol for the report, and we spent half of a three-hour class engaged in roleplaying about the ways that students would learn the information they needed from talking with welfare recipients and others. Looking back, there are important ways that the course can be improved, particularly by better integrating community service, class discussions, readings, and field surveys. But this initial effort was a true success in terms of fostering civic learning, in the views of both the students and agencies involved. Ms. Bamberger and I did extensive surveys of attitudes, interests, and involvement in civic affairs both at the start and end of the course. Those surveys indicate that most of the participating students expected to remain active and engaged citizen leaders of San Francisco-or another community-for the rest of their lives, regardless of career choice, and that the course had a real effect on that expectation. The differences between before and after were not great, but they were positive. The first survey question, for example, asked how strongly students agreed or disagreed with the statement, "Adults should give some time for the good of their community." In the initial survey, half agreed, and half agreed strongly. By the second survey, all but two agreed strongly. At the beginning of the semester, a slight majority said that they neither agreed nor disagreed that "It is important to me to become a community leader," and the rest agreed with the statement. By the end, a strong majority agreed, and several agreed strongly. Finally, at the start of the course many students were ambivalent about the statement that "Volunteer service will/would be valuable in my career," but by the end, all of the students agreed, and most students agreed strongly.

I do not want to overstate the importance of the survey results, but the increase in students' commitment to political engagement and civic 
leadership was supported by other assessments. Discussions with the students over the course of the semester confirmed that the shifts were significant. We also conducted a general course evaluation at the end of the semester, which revealed strong student support for the course and the need for more efforts to integrate the course readings, discussions, community service, and projects. Of course, 15 is a small number of students and there may have been a selection bias as most of the students probably came to the class with a higher level of civic engagement than the average student. The surveys and other evaluations suggest, however, that even those students who joined the class with what may have been higher-than-average levels of civic engagement probably came away from the course with an even stronger commitment to active political participation and community involvement.

\section{LESSONS LEARNED}

Experiences such as this one persuade me that civic responsibility is not a dimension of learning that can be pasted on a student's character while she or he learns calculus. Rather, it is a complex combination of cognitive and emotional learning. To gain clearer insight into what works in this realm, my colleague at the Carnegie Foundation for the Advancement of Teaching, Anne Colby, and I have a major project underway. The focus of our project is undergraduate education and the development of moral and civic responsibility. We are examining current efforts at colleges and universities to enhance moral and civic responsibility, and also helping to strengthen those efforts. We are identifying programs that are wellgrounded in a thoughtful conceptual framework, that engage strong student and faculty interest, and that provide experiences which challenge students both intellectually and morally. We also plan to make detailed information about those programs easily accessible. Most important, we want to encourage and support serious concern about the development of undergraduates' moral and civic responsibility among faculty and administrative leaders. The overall aim of the project is to aid colleges and universities in better preparing their students to be informed, committed, socially responsible, and ethically conscientious citizens.

We are not seeking to isolate moral and civic learning from intellectual learning. To the contrary, we believe that intellectual learning is inadequate unless it is infused with moral and civic learning, and that moral and civic learning is ineffective unless it is integrated with rigorous intellectual learning. Nothing is more important to enhancing civic 
responsibility than this integration. We are exploring the tensions in finding sound balance between an educational experience that is rooted in a strong values-based campus, with its dangers of indoctrination and political correctness, and a campus that promotes open and objective inquiry to the exclusion of preparing students to make their own moral and civic judgments.

Our project is identifying policies and practices that promote the capacities of undergraduates to make reasoned judgments that are infused with moral and civic concerns. We do not expect to provide rigorous assessments of those policies and practices, although that may be attempted in subsequent stages. But we do expect to provide evidence that particular efforts are intended to help students develop the capacities needed to reach judgments that include moral and ethical considerations, and that those efforts have the intended effects.

Our project is consciously and closely tied to the other work of the Carnegie Foundation for the Advancement of Teaching. One is the Carnegie Academy, which is a project on the scholarship of teaching. The project has three components. The first is a program to help a group of faculty in a variety of fields (chemistry, English, management, and psychology in our first year) engage in that scholarship through two ten-day summer periods together, and through further interactions over the academic year. The second is a network of associated campuses, each of which is working to foster and support faculty work on the scholarship of teaching. And the third is collaboration with a number of disciplinary and professional organizations that are also interested in promoting the scholarship of teaching. The other main program at the Carnegie Foundation is focused on preparation for the professions; and will examine that preparation over a five-year period, with particular attention to law, engineering, medicine, social work, the clergy, and education. We are encouraging faculty at the campuses we are studying to participate in the Carnegie Teaching Academy and their campuses to affiliate with the Academy. We are also focusing significant attention in the professions program on issues of moral and civic responsibility, and we expect that those issues will also be central in the design of the project on preparing future college and university teachers.

The project began only last year, but already we have learned some lessons. Five seem to me particularly relevant here:

1) Moral and civic learning are interconnected. This may seem obvious to some, but it is certainly resisted by others. To us, however, the ev- 
idence is overwhelming that a strong moral compass is needed as a predicate to civic engagement.

2) The development of moral and civic character is not on the radar screens of most colleges and universities except as a matter of public relations rhetoric. Almost all institutions do refer to these goals for students in their mission statements. At most colleges and universities, however, the mission statement is ignored, indeed unknown, by administrators, faculty, and students. Our Carnegie colleague, William M. Sullivan (2000), has persuasively argued that "much of higher education has come to operate on a sort of default program of instrumental individualism. This is the familiar notion that the academy exists to research and disseminate knowledge and skills as tools for economic development and the upward mobility of individuals" (p. 4). Sullivan laments that a consequence of this default program of instrumental individualism is that leadership in both the private and public sectors is increasingly dominated by "narrow careerism and private self-interest" (p. 5).

3) Our initial explorations indicate that the most effective strengthening of moral and civic character occurs on campuses where curricular and extracurricular learning experiences are consciously woven into a larger, integrated whole. The campus culture at these institutions is key in their shaping of civic and moral learning. At this stage, it may be more accurate to term this judgment a premise rather than a lesson learned. It is the basis for our choices, for in-depth studies, of a small group of colleges and universities that exhibit a high degree of intentionality about the education of their students.

4) We believe that important contributions to moral and civic learning can be made by a variety of different curricular and extracurricular approaches, among the overwhelming majority of campuses that do not have any degree of institutional intentionality about enhancing the civic and moral character of their students. Curricular approaches include required courses in ethics, freshman seminars, capstone experiences, faculty seminars to encourage faculty to bring moral and civic issues into their discussions of course material, and curricular sequences that aim to help students shape their lives and work in civically and morally committed directions. In addition, many campuses emphasize the three pedagogies I mentioned that hold great potential for civic engagement: service-learning, collaborative 
learning, and problem-based learning. A fourth, one that can be especially exploited at research universities, is linking undergraduate research to current community concerns.

Numerous colleges and universities also have centers or institutes that focus on civic responsibility, social change, and various aspects of ethics. The missions of these centers vary, but most include both curricular and extracurricular activities, such as student leadership development programs, programs of university/community partnerships around pressing social issues, and special residence hall experiences.

We are examining the efforts of a wide range of institutions under various categories, including freshman seminars, capstone programs, ethics across the campus, academic centers, student leadership programs, and faculty leadership programs. Within each category, we are trying to identify good practices.

5) In some ways most important, all of us in higher education need clearer, stronger frameworks for the integration of both civic and moral learning and the more common cognitive learning that occurs in traditional classrooms. I suspect we all have a tendency to separate the civic and moral from the intellectual in our teaching, to worry that we are not being professional if we bring our normative judgments about moral or civic issues into the classroom. And certainly there are real tensions in helping students both in developing their own civic and moral stands and in translating those stands into action, while at the same time avoiding inculcation. But the moral and intellectual relativism that comes from setting forth competing theories of urban decay, for example, without helping students reach their own moral and civic judgments on which theory or combination of theories is most compelling, is an abdication of faculty responsibility.

\section{Conclusion}

Time and again over the past months, I have heard faculty members in fields such as political science, philosophy, psychology, and economics say that their only role is to report, to analyze, to criticize. Whether and how their students develop moral and civic judgments-let alone translate those judgments in action-is not their business. This approach is dangerous for our democracy. Our students need to integrate and balance intellectual virtues and moral and civic virtues that together will enable them to make judgments and to act on those judgments. 
In the end, higher education should be devoted not just to the spread of knowledge, but to the pursuit of virtuous action. It should have an impact on how students make the important choices that shape their lives. That goal cannot be achieved, of course, without faculty who are not only dedicated to enhancing the civic responsibility of their students, but also prepared to do so through programs of faculty development. The combinations of knowledge, skills, and values that together can enable students to become active participants in their communities must be learned first by faculty. The faculty, in turn, need assistance in transmitting those combinations to students in ways that do not inculcate but rather enable them to make their own civic judgments and to act on those judgments. This is a vital role for faculty development, one that has been too long neglected.

\section{ACKNOWLEDGMENTS}

My thanks to Lori Bamberger and to Elizabeth Beaumont for assistance in preparing this essay. Portions of this essay, in somewhat different form, were published in PS: Political Science $\sim$ Politics, 32 (2), pp. 245-250, and 1999, September/October About Campus, 4 (4), pp. 5-9.

\section{REFERENCES}

Barber, B. (1992). An aristocracy of everyone: The politics of education and the future of America. New York, NY: Ballantine.

Barber, B., \& Battistoni, R. (Eds.). (1993). Education for democracy. Dubuque, IA: Kendall/Hunt.

Barber, B., \& Battistoni, R. (1993). A season of service: Introducing service-learning into the liberal arts curriculum. PS: Political Science and Politics, 26 (pp. 235-262). Dubuque, IA: Kendall/Hunt.

Battistoni, R., \& Hudson, W. (Eds.). (1997). Experiencing citizenship: Concepts and models for service-learning in political science. Washington, DC: American Association for Higher Education.

Boyte, H, \& Kari, N. (1996). Building America: The democratic promise of public work. Philadelphia, PA: Temple University Press.

Danzinger, S. H., Sandefur, G. D., \& Weinberg D. H. (Eds.). (1994). Confronting poverty: Prescriptions for change. Cambridge, MA: Harvard University Press.

Dewey, J. (1916). Democracy and education. New York, NY: Macmillan. 
Dewey, J. (1938). Experience and education. New York, NY: Collier Books.

Jackson, K. (Ed). (1994). Redesigning curricula. Providence, RI: Campus Compact.

Putnam, R. (1995, January). Bowling alone. Journal of Democracy, 6, pp. 65-78.

Rahn, W. (1998, May 8-9). Generations and American national identity: A data essay. Presentation at the Communication in the Future of Democracy Workshop. Washington, DC: Annenberg Center.

Rothman, M. (Ed.). (1998). Service matters. Providence, RI: Campus Compact.

Sullivan, W. M. (2000). Institutional identity and social responsibility. In T. Ehrlich (Ed.), Civic responsibility and higher education (pp. 19-36). Phoenix, AZ: Oryx Press.

\section{Contact:}

Thomas Ehrlich

Distinguished University Scholar

San Francisco State University

Senior Scholar, The Carnegie Foundation for the Advancement of Teaching 555 Middlefield Rd.

Menlo Park, CA 94025

(650) 566-5137

Email: ehrlich@carnegiefoundation.org

Thomas Ehrlich is Senior Scholar at the Carnegie Foundation for the Advancement of Teaching and distinguished University Scholar at San Francisco State University. He was formerly president of Indiana University, provost of the University of Pennsylvania, and dean of Stanford Law School. He was also the first president of the Legal Services Corporation and the first head of the International Development Cooperation Agency, reporting to President Carter. He serves on many boards, including Bennett College, the Corporation for $\mathrm{Na}$ tional Service, and the Public Welfare Foundation, and is chair of the board of the American Association for Higher Education. He is author or coauthor of eight books, many articles and reviews, and has received four honorary degrees. 